\title{
Perbandingan Efektivitas Kombinasi Fentanyl-Paracetamol dan Fentanyl-Ketorolac terhadap Numerical Rating Scale (NRS) Post Operasi Seksio Sesarea
}

\author{
Andy H, Sugeng Budi Santoso, RTH Supraptomo \\ Departemen Anestesiologi \& Terapi Intensif Fakultas Kedokteran Universitas Sebelas Maret-RSUP Dr. Moewardi \\ Surakarta
}

\begin{abstract}
Abstrak
Latar Belakang: Nyeri post operasi seksio sesarea merupakan nyeri sedang berat dengan intensitas akut. Saat ini terdapat dua kombinasi obat anti nyeri yang umum digunakan untuk mengatasi nyeri post operasi seksio sesarea yaitu kombinasi paracetamol-fentanyl serta kombinasi ketorolac-fentanyl. Interaksi kedua obat tersebut dapat menurunkan ambang nyeri yang dapat kita periksa dengan skor Numerical Rating Scale (NRS).

Tujuan: Untuk mengetahui adanya perbedaan efektivitas antara pemberian kombinasi paracetamol-fentanyl dengan ketorolac-fentanyl dalam mengatasi nyeri post operasi seksio sesarea.

Subjek dan Metode: Penelitian eksperimental dengan pendekatan uji klinis menggunakan 30 subjek pasien hamil dengan umur 20-40 tahun dengan status fisik ASA I-II yang akan menjalani operasi seksio sesarea dengan spinal anestesi lidocain 5\% hiperbarik. Grup pertama diberikan $1000 \mathrm{mg}$ paracetamol dan 0,3mcg/ $\mathrm{kg} / \mathrm{jam}$ fentanyl intravena sebagai analgesik. Grup ke 2 diberikan ketorolac 30mg dan fentanyl o,3mcg/kg/jam. Pada penelitian ini dilakukan analisis univariat dan bivariat.

Hasil: Hasil uji beda terhadap karakteristik subyek penelitian didapatkan pada kelompok paracetamol dan fentanyl terdapatperbedaanyangsignifikanpadapostoperasidengannilaip $=0,005(\mathrm{p}<0,05)$, padaketorolacdanfentanylterdapat perbedaan yang signifikan post operasi dengan nilai $\mathrm{p}=0,023(\mathrm{p}<0,05)$ dimana kelompok paracetamol dan fentanyl dengan skor NRS cenderung turun, dan kelompok ketorolac dan fentanyl dengan skor NRS cenderung meningkat. Simpulan: Kombinasi paracetamol fentanyl lebih efektif dibandingkan dengan ketorolac fentanyl.
\end{abstract}

Kata kunci: fentanyl, ketorolac, nyeri pasca seksio sesarea, paracetamol

\section{The Comparison of the Effectiveness of Combination Fentanyl-Paracetamol with Fentanyl-Ketorolac on Numerical Rating Scale (NRS) Post Caesarean Section}

\begin{abstract}
Background: Postoperative cesarean section pain is moderate-to-severe pain with acute intensity. There are two common anti-pain drug combinations used to treat post-cesarean section pain, namely the parasetamol-fentanyl combination and the ketorolac-fentanyl combination. The interaction of the two drugs can lower the pain threshold which we can check with the Numerical Rating Scale (NRS) score.

Objective: To determine the difference in effectiveness between the combination of parasetamol-fentanyl and ketorolac-fentanyl in dealing with post-cesarean section surgery pain.

Subject and Method: This study is an experimental study with a clinical trial approach using 30 subjects of pregnant patients aged 20-40 years with ASA I-II physical status who will undergo cesarean section surgery with hyperbaric 5\% lidocaine spinal anesthesia. The first group were given $1000 \mathrm{mg}$ parasetamol and $0.3 \mathrm{mcg} / \mathrm{kg} / \mathrm{h}$ fentanyl intravenous as analgesics. The second group were given ketorolac $30 \mathrm{mg}$ and fentanyl $0.3 \mathrm{mcg} / \mathrm{kg} / \mathrm{h}$ intravenously. In this study, univariate and bivariate analyzes were performed.

Results: The results of different tests on the characteristics of research subjects were found in the parasetamol and fentanyl groups, there was a significant difference in the post-operation with a value of $p=0.005(p<0.05)$, in ketorolac and fentanyl there was a significant difference post-surgery with a value of $p=0.023(p<0.05)$ where the paracetamol and fentanyl groups with NRS scores tended to fall, and the ketorolac and fentanyl groups with NRS scores tended to increase.
\end{abstract}

Conclusion: The combination of paracetamol and fentanyl was more effective than ketorolac and fentanyl.

Key words: fentanyl, ketorolac, pain after cesarean section, parasetamol 


\section{Pendahuluan}

Pada tahun 2007 diperkirakan 15\% dari kelahiran di seluruh dunia terjadi dengan operasi seksio sesarea. Di negara berkembang, proporsi kelahiran dengan cara seksio sesarea berkisar $21,1 \%$ dari total kelahiran yang ada, sedangkan di negara maju hanya $2 \%^{1}$ Nyeri pasca operasi seksio sesarea termasuk nyeri akut sedang berat, dimana memerlukan obat analgetik yang adekuat dalam manajemen pasca operasi seksio sesarea. ${ }^{2,3}$ Paracetamol memiliki penghambatan prostaglandin sentral yang setara dengan aspirin. Paracetamol bekerja melalui 3 mekanisme: menghambat sintesis prostaglandin di sel, menghambat enzim siklooksigenase di pusat, dan bekerja di kemoreseptor nyeri di perifer. $^{3}$ Ketorolac merupakan obat anti inflamasi non-steroid (OAINS) non selektif. Ketorolac bekerja melalui penghambatan enzim enzim siklo-oksigenase (COX) 1 dan $2 .{ }^{4}$

Fentanyl adalah zat sintetik seperti petidin dengan kekuatan 100x morfin. Fentanyl merupakan opioid sintetik dari kelompok fenilpiperedin. Lebih larut dalam lemak dan lebih mudah menembus sawar jaringan. Dosis fentanyl dan opioid yang lain sangat lebar dan bisa dikurangi $20 \%-50 \%$ apabila dikombinasikan dengan OAINS. 5 Nyeri pasca operasi seksio sesarea merupakan nyeri sedang berat dengan intensitas akut. Sesuai dengan bagan tangga nyeri World Health Organization (WHO) tahun 2015, penangan nyeri sedang berat akut diawali dengan analgetik kuat kemudian baru diturunkan dosisnya perlahan. Bisa dengan pemberian opioid kuat dengan kombinasi OAINS atau adjuvant yang lain. ${ }^{6}$ Tujuan dari penelitian ini adalah untuk mengetahui adanya perbedaan efektivitas antara pemberian kombinasi paracetamol-fentanyl dengan ketorolac-fentanyl dalam mengatasi nyeri pasca operasi seksio sesarea.

\section{Subjek dan Metode}

Desain Studi

Penelitian ini merupakan jenis penelitian eksperimental dengan pendekatan uji klinis untuk membandingkan efektivitas penggunaan kombinasi paracetamol 1 gram + fentanyl 0,3 $\mathrm{mcg} / \mathrm{kgBB} / \mathrm{jam}$ dengan kombinasi ketorolac 30 $\mathrm{mg}+$ fentanyl $0,3 \mathrm{mcg} / \mathrm{kgBB} / \mathrm{jam}$ untuk analgetik pasca operasi seksio sesarea dengan menilai skoring nyeri menggunakan numerical rating scale (NRS). Penelitian dilakukan di instalasi bedah sentral dan kamar rawat inap rumah sakit umum daerah (RSUD) Dr. Moewardi Surakarta mulai bulan Oktober-Desember tahun 2016.

\section{Populasi dan Sampel}

Populasi sasaran adalah pasien hamil usia 2040 tahun yang menjalani operasi seksio sesarea dengan anestesi spinal dengan status fisik ASA I dan II. Populasi terjangkau adalah pasien usia 20 - 40 tahun yang menjalani operasi seksio sesarea dengan anestesi spinal, ASA I dan II, di instalasi bedah sentral RSUD Dr. Moewardi Surakarta dan telah mendapatkan informed consent. Sampel adalah sebagian dari populasi yang memenuhi kriteria inklusi dan eksklusi penelitian. Kriteria inklusi dalam penelitian ini adalah semua pasien yang dijadwalkan operasi seksio sesarea dengan usia 20-40 tahun, status fisik ASA I dan ASA II, dan menjalani operasi dengan spinal anestesi menggunakan lidocain 5\% hiperbarik. Sedangkan kriteria ekskusi adalah pasien dengan obesitas morbid (Indeks Massa Tubuh $>40 \mathrm{kgBB} / \mathrm{m} 2$ ), pasien menjalani operasi dengan anestesi umum, pasien dengan kelainan jantung berat (hipertensi tidak terkontrol, hipertensi akut dan gangguan koroner yang berat), alergi terhadap obat-obatan anestesi, riwayat gangguan penyalahgunaan obat-obatan NAPZA atau gangguan psikiatrik, menolak menandatangani informed consent, menggunakan obat-obat sedasi perioperatif. Semua pasien yang memenuhi kriteria inklusi dan eksklusi diberi penjelasan secara lisan dan menandatangani lembar persetujuan untuk ikut dalam penelitian secara sukarela. Bila karena suatu alasan penderita/keluarga penderita berhak mengundurkan diri dari penelitian ini.

Pada penelitian ini terdapat dua variabel bebas yaitu obat paracetamol dan ketorolac serta satu variabel terikat yaitu skor Numeric Rating Scale. Penelitian ini menggunakan teknik pengambilan sampel berupa purposive sampling, dimana jumlah minimum sampel dapat dihitung menggunakan 
pedoman "rule of thumb" yaitu 30 subyek penelitian. Sebelum dilakukan pengelompokan sampel telah dilakukan ranndomisasi dan penyamaran menggunakan teknik randomisasi single blinded. Distribusi sampel meliputi 15 subyek dengan pemberian analgetik kombinasi parasetamol dan fentanyl serta 15 subyek dengan pemberian analgetik kombinasi ketorolak dan fentanyl.

\section{Variabel Penelitian}

Variabel bebas berupa pemberian analgetik yaitu ketorolac $30 \mathrm{mg}$ dan fentanyl $0,3 \mathrm{mcg} /$ $\mathrm{kgBB} / \mathrm{jam}$, paracetamol $1 \mathrm{gr}+$ fentanyl $0,3 \mathrm{mcg} /$ $\mathrm{kgBB} / \mathrm{jam}$. Variabel terikat berupa skor Numeric Rating Scale. Skor NRS adalah skala linier untuk menggambarkan derajat nyeri dengan angka 0-10, 0: sama sekali tidak nyeri dan 10: sangat nyeri yang tidak tertahankan lagi.

\section{Instrumen Penelitian}

Subjek akan dibagi menjadi dua kelompok, yaitu kelompok paracetamol-fentanyl (PF) dan kelompok ketorolac-fentanyl (KF), setiap kelompok terdiri dari 15 pasien. Pasien yang menjalani operasi seksio sesarea diberikan salah satu perlakuan di atas menjelang operasi selesai atau ketika dilakukan penjahitan subcutis. Penilaian untuk skoring nyeri dilakukan di ruangan perawatan tiap 2 jam dengan dicatat Numeric Rating Scale dan tanda vital sampai 8 jam pertama.

\section{Uji Cohen's Kappa}

Data yang terkumpul diolah dengan pengolahan data deskriptif. Untuk mengetahui tingkat persamaan antar responden dilakukan dengan Uji Cohen's Kappa. Apabila Kappa value berada pada rentang 0,62-0,76 maka tingkat persamaan persepsi dinyatakan hampir sempurna.

\section{Follow Up dan Outcome}

Pada penelitian ini akan dilakukan follow up setiap 2 jam setelah pemberian perlakuan hingga 8 jam setelah pemberian perlakuan. Primary outcome dalam penelitian ini adalah perbandingan penurunan skor NRS setelah pemberian obat analgetik. Secondary outcome pada penelitian ini adalah untuk mengetahui perbandingan pilihan obat analgetik terbaik pasca operasi seksio sesarea.

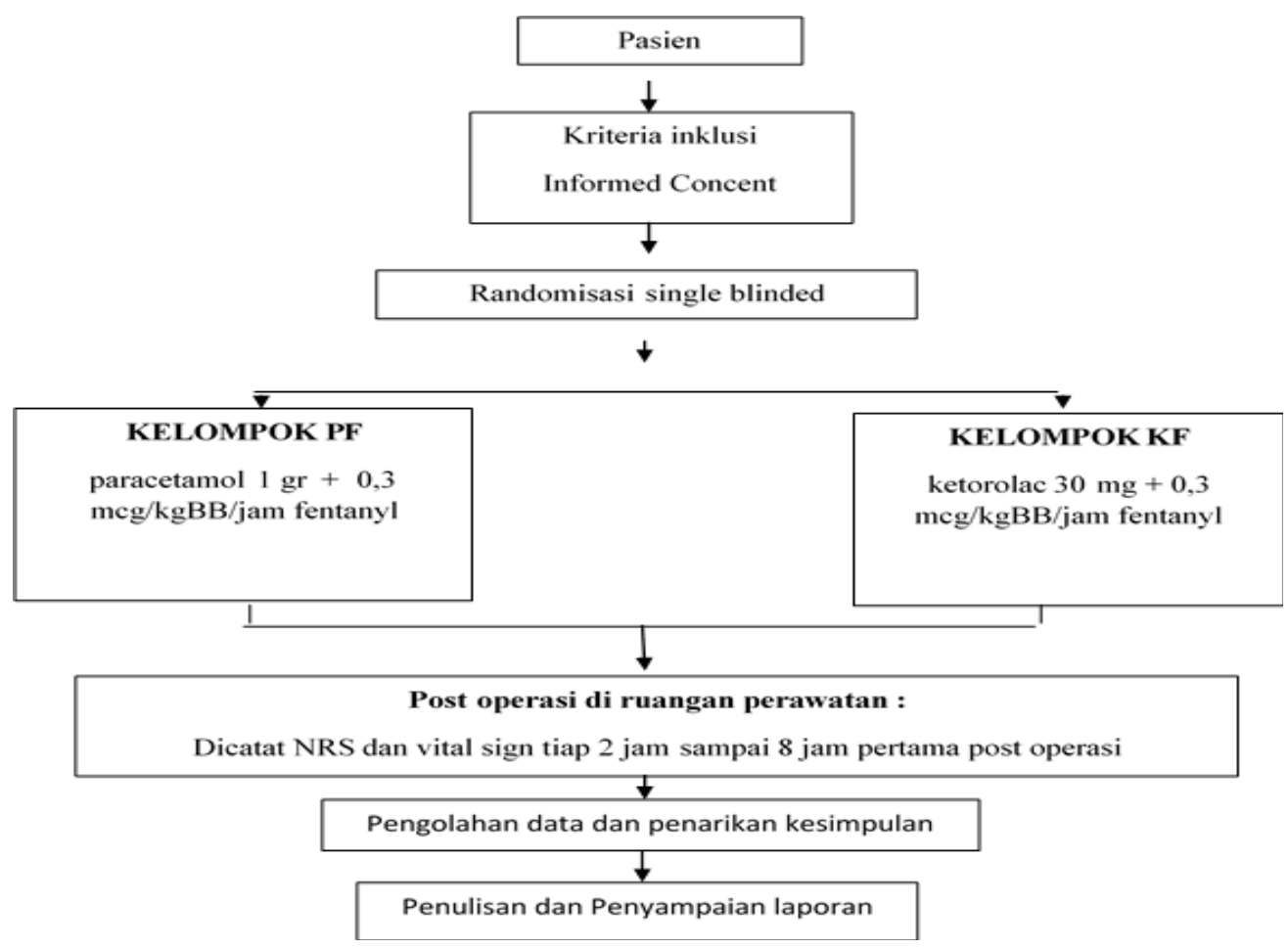

Gambar 1. Bagan Alur Penelitian 


\section{Analisis Data}

Analisis data dalam penelitian ini akan dilakukan dalam bentuk analisis univariat dan analisis bivariat. Analisis data dilakukan menggunakan program SPSS versi terbaru 25.0. Pada penelitian ini akan diukur perbandingan NRS pada kelompok parasetamol + fentanyl dengan kelompok ketorolac + fentanyl pada 2 jam pasca operasi, 4 jam pasca operasi, 6 jam pasca operasi, dan 8 jam pasca operasi menggunakan uji analisis univariat dan bivariat. Pada analisis univariat, variabel dari data demografi dicari nilai reratanya. Pada analisis bivariat, perbandingan variabel pada masing-masing kelompok diuji dengan menggunakan uji t test, uji Mann Whitney, dan uji Friedman untuk data nominal dan ordinal. Penelitian ini menggunakan batas kemaknaan 0,05 dan interval kepercayaan $95 \%$.

\section{Etika Penelitian}

Subjek penelitian yang telah memenuhi syarat telah diminta persetujuannya secara tertulis dengan menandatangani informed consent. Data identitas penelitian dirahasiakan, dan seluruh biaya yang berhubungan dengan penelitian menjadi tanggung jawab peneliti. Pada penelitian ini juga dimintakan ethical clearance dari Komisi Etik Penelitian Kesehatan Fakultas Kedokteran Universitas Sebelas Maret Surakarta dan Rumah Sakit Dr. Moewardi. Penelitian ini mendapat persetujuan ethical clearance dengan nomor 697/V/HREC/2020.

\section{Hasil}

Penelitian ini dilakukan pada 30 pasien usia 20 - 40 tahun yang memiliki status fisik ASA I dan II yang menjalani operasi seksio sesarea dengan anestesi spinal menggunakan lidocain 5\% di instalasi bedah sentral RSUD Dr. Moewardi Surakarta dan telah mendapatkan informed consent. Selama penelitian berlangsung, seluruh peserta dapat mengikuti penelitian sesuai prosedur tanpa ada yang mengalami dropout. Seluruh pasien diberi penjelasan (informed consent) mengenai prosedur yang dialami oleh pasien selama penelitian ini. Selanjutnya, secara acak pasien dibagi menjadi dua kelompok, setiap kelompok terdiri dari 15 pasien. Kelompok (PF): paracetamol $1 \mathrm{gr}+0,3 \mathrm{mcg} / \mathrm{kgBB} / \mathrm{jam}$ fentanyl dan kelompok (KF): ketorolac $30 \mathrm{mg}+0,3 \mathrm{mcg} /$ $\mathrm{kgBB} / \mathrm{jam}$ fentanyl.

Pasien yang menjalani operasi seksio sesarea diberikan salah satu perlakuan di atas menjelang operasi selesai atau ketika dilakukan penjahitan subcutis. Penilaian untuk skoring nyeri dilakukan di ruangan perawatan tiap 2 jam dengan dicatat skor NRS dan tanda vital sampai 8 jam pertama.

Penelitian ini bertujuan untuk mengetahui perbedaan efektivitas pemberian kombinasi paracetamol dan fentanyl dengan ketorolac dan fentanyl sebagai analgetik pasca operasi seksio sesarea. Pengukuran nyeri menggunakan skor NRS untuk menggambarkan derajat nyeri dengan angka $0-10$, 0 : sama sekali tidak nyeri dan 10 : sangat nyeri yang tidak tertahankan lagi.

Pasien yang diberi perlakuan paracetamol + fentanyl diketahui bahwa skor NRS 2 jam post operasi sebagian besar dalam kategori ringan yaitu ada 8 pasien dan sisanya dalam kategori sedang yaitu ada 7 pasien. Skor NRS 4 jam post operasi sebagian besar dalam kategori ringan yaitu ada 12 pasien, dan sisanya dalam kategori sedang yaitu ada 3 pasien. Skor NRS 6 jam post operasi sebagian besar dalam kategori ringan yaitu ada 12 pasien, dalam kategori sedang yaitu ada 2 pasien, dan dalam kategori tidak nyeri ada 1 pasien. Skor NRS 8 jam post operasi sebagian besar dalam kategori ringan yaitu ada 14 pasien, sisanya dalam kategori sedang yaitu ada 1 pasien. Hasil evaluasi NRS 15 pasien yang diberikan paracetamol+fentanyl dijelaskan pada tabel 1 .

Pasien yang diberi perlakuan ketorolac + fentanyl diketahui bahwa sebagian besar dalam kategori ringan yaitu ada 9 pasien $(60,0 \%)$, dalam kategori sedang yaitu ada 5 pasien $(33,3 \%)$, dan dalam kategori tidak nyeri ada 1 pasien $(6,7 \%)$. Skor NRS 4 jam post operasi sebagian besar dalam kategori sedang yaitu ada 8 pasien $(53,3 \%)$, dalam kategori ringan yaitu ada 6 pasien $(40,0 \%)$, dan dalam kategori tidak nyeri ada 1 orang $(6,7 \%)$. Skor NRS 6 jam post operasi sebagian besar dalam kategori sedang yaitu ada 11 pasien $(73,3 \%)$, sisanya dalam kategori ringan yaitu ada 4 pasien $(26,7 \%)$. Skor NRS 8 jam post operasi 
Tabel 1. Gambaran Tingkat Nyeri pada Kelompok Paracetamol+Fentanyl

\begin{tabular}{clllllllc}
\hline No Pasien & \multicolumn{2}{c}{$\begin{array}{c}\text { NRS 2 Jam Pasca } \\
\text { Operasi }\end{array}$} & \multicolumn{2}{c}{$\begin{array}{c}\text { NRS 4 Jam Pasca } \\
\text { Operasi }\end{array}$} & \multicolumn{2}{c}{$\begin{array}{c}\text { NRS 6 Jam Pasca } \\
\text { Operasi }\end{array}$} & \multicolumn{2}{c}{$\begin{array}{c}\text { NRS 8 Jam Pasca } \\
\text { Operasi }\end{array}$} \\
\hline & Skor & Kategori & Skor & Kategori & Skor & Kategori & Skor & Kategori \\
\cline { 2 - 8 } & 3 & Ringan & 2 & Ringan & 2 & Ringan & 3 & Ringan \\
3 & 4 & Sedang & 3 & Ringan & 2 & Ringan & 2 & Ringan \\
4 & 4 & Sedang & 4 & Sedang & 4 & Sedang & 4 & Sedang \\
5 & 3 & Ringan & 2 & Ringan & 3 & Ringan & 3 & Ringan \\
6 & 2 & Ringan & 2 & Ringan & 2 & Ringan & 2 & Ringan \\
7 & 6 & Ringan & 2 & Ringan & 2 & Ringan & 2 & Ringan \\
8 & 3 & Sedang & 4 & Sedang & 3 & Ringan & 3 & Ringan \\
9 & 5 & Ringan & 3 & Ringan & 2 & Ringan & 2 & Ringan \\
10 & 4 & Sedang & 3 & Ringan & 3 & Ringan & 3 & Ringan \\
11 & 3 & Sedang & 3 & Ringan & 2 & Ringan & 2 & Ringan \\
12 & 2 & Ringan & 2 & Ringan & 2 & Ringan & 2 & Ringan \\
13 & 6 & Ringan & 3 & Ringan & 4 & Sedang & 3 & Ringan \\
14 & 5 & Sedang & 3 & Ringan & 3 & Ringan & 3 & Ringan \\
15 & 3 & Sedang & 5 & Sedang & 2 & Ringan & 2 & Ringan \\
\hline Rata-rata & 3,60 & Ringan & 1 & Ringan & 0 & Tidak nyeri & 1 & Ringan \\
\hline & & & 2,80 & & 2,40 & & 2,47 & \\
\hline
\end{tabular}

Tabel 2. Gambaran Tingkat Nyeri pada Kelompok Ketorolac+Fentanyl

\begin{tabular}{cllllllll}
\hline No Pasien & \multicolumn{2}{c}{$\begin{array}{c}\text { NRS 2 Jam Pasca } \\
\text { Operasi }\end{array}$} & \multicolumn{2}{c}{$\begin{array}{c}\text { NRS 4 Jam Pasca } \\
\text { Operasi }\end{array}$} & $\begin{array}{c}\text { NRS 6 Jam Pasca } \\
\text { Operasi }\end{array}$ & $\begin{array}{c}\text { NRS 8 Jam Pasca } \\
\text { Operasi }\end{array}$ \\
\hline & Skor & Kategori & Skor & Kategori & Skor & Kategori & Skor & Kategori \\
\cline { 2 - 8 } 2 & 4 & Sedang & 4 & Sedang & 4 & Sedang & 4 & Sedang \\
3 & 4 & Ringan & 2 & Ringan & 2 & Ringan & 2 & Ringan \\
4 & 6 & Sedang & 5 & Sedang & 5 & Sedang & 5 & Sedang \\
5 & 3 & Sedang & 3 & Ringan & 4 & Sedang & 4 & Sedang \\
6 & 3 & Ringan & 4 & Sedang & 4 & Sedang & 4 & Sedang \\
7 & 3 & Ringan & 6 & Sedang & 5 & Sedang & 5 & Sedang \\
8 & 3 & Ringan & 3 & Ringan & 4 & Sedang & 4 & Sedang \\
9 & 1 & Ringan & 3 & Ringan & 4 & Sedang & 4 & Sedang \\
10 & 3 & Ringan & 4 & Sedang & 4 & Sedang & 4 & Sedang \\
11 & 2 & Ringan & 5 & Sedang & 5 & Sedang & 5 & Sedang \\
12 & 4 & Sedang & 3 & Ringan & 3 & Ringan & 5 & Sedang \\
13 & 0 & Tidak nyeri & 0 & Tidak nyeri & 3 & Ringan & 3 & Ringan \\
14 & 3 & Ringan & 4 & Sedang & 4 & Sedang & 5 & Sedang \\
15 & 6 & Sedang & 3 & Ringan & 3 & Ringan & 4 & Sedang \\
\hline Rata-rata & 3,20 & & 3,60 & & 3,93 & & 4,20 & Sedang \\
\hline & & & & & & & 5 & \\
\hline
\end{tabular}


Tabel 1. Perbedaan Efektivitas Pemberian Parasetamol dengan Ketorolac sebagai Analgetik Post Operasi Seksio Sesarea

\begin{tabular}{llllll}
\hline Kelompok & NRS 2 jam* & NRS 4 jam* & NRS 6 jam** & NRS 8 jam** & P*** \\
\hline Paracetamol & $3,60 \pm 1,45$ & $2,80 \pm 1,01$ & $2 ., 0 \pm 0,99$ & $2,47 \pm 0,74$ & 0,005 \\
Ketorolac & $3,20 \pm 1.57$ & $3,60 \pm 1,45$ & $3,93 \pm 0,88$ & $4,20 \pm 0,86$ & 0,023 \\
P & 0,495 & 0,091 & 0,000 & 0,000 & \\
\hline
\end{tabular}

Ketengan: *uji beda kelompok tidak berpasangan data berdistribusi normal;uji t test

**uji beda kelompok tidak berpasangan data berdistribusi tidak normal;uji Mann Witney

*** uji beda kelompok berpasangan data berdistribusi tidak normal; Uji Friedman

sebagian besar dalam kategori sedang yaitu ada 13 pasien $(86,7 \%)$, sisanya dalam kategori ringan yaitu ada 2 pasien (13,3\%). Hasil evaluasi NRS 15 pasien yang diberikan ketorolac+fentanyl dijelaskan pada tabel 2.

Berdasarkan tabel 3 diketahui bahwa pada 2 jam pasca operasi diketahui antara kelompok paracetamoldanketorolactidakterdapatperbedaan yang signifikan dengan nilai $\mathrm{p}=0,495(\mathrm{p}>0,05)$, dimana NRS pada kelompok paracetamol ratarata 3,60 + 1,45 dan ketorolac rata-rata 3,20 $+1,57$. Pada 4 jam pasca operasi diketahui antara kelompok paracetamol dan fentanyl dan ketorolac tidak terdapat perbedaan yang signifikan dengan nilai $p=0,091(p>0,05)$, dimana NRS pada kelompok paracetamol rata-rata 2,80 $+1,01$ dan ketorolac rata-rata 3,60+1,45. Pada 6 jam pasca operasi diketahui antara kelompok paracetamol dan ketorolac terdapat perbedaan yang signifikan dengan nilai $\mathrm{p}=0,000(\mathrm{p}<0,05)$, dimana NRS pada kelompok paracetamol ratarata 2,40+0,99 dan ketorolac rata-rata 3,93+0,88. Pada 8 jam pasca operasi diketahui antara kelompok paracetamol dan fentanyl dengan ketorolac dan fentanyl terdapat perbedaan yang signifikan dengan nilai $\mathrm{p}=0,000(\mathrm{p}<0,05)$, dimana NRS pada kelompok parasetamol dan fentanyl rata-rata $2,47+0,74$ dan ketorolac dan fentanyl rata-rata $4,20+0,86$. Pada kelompok paracetamol terdapat perbedaan yang signifikan pada jam ke-2, ke-4, ke-6, dan ke-8 pasca operasi dengan nilai $\mathrm{p}=0,005(\mathrm{p}<0,05)$, pada ketorolac terdapat perbedaan yang signifikan pada jam ke2 , ke-4, ke-6, dan ke-8 pasca operasi dengan nilai $\mathrm{p}=0,023(\mathrm{p}<0,05)$ dimana kelompok paracetamol dengan skor NRS cenderung turun, dan kelompok ketorolac dengan skor NRS cenderung meningkat. Berdasarkan uraian diatas diketahui

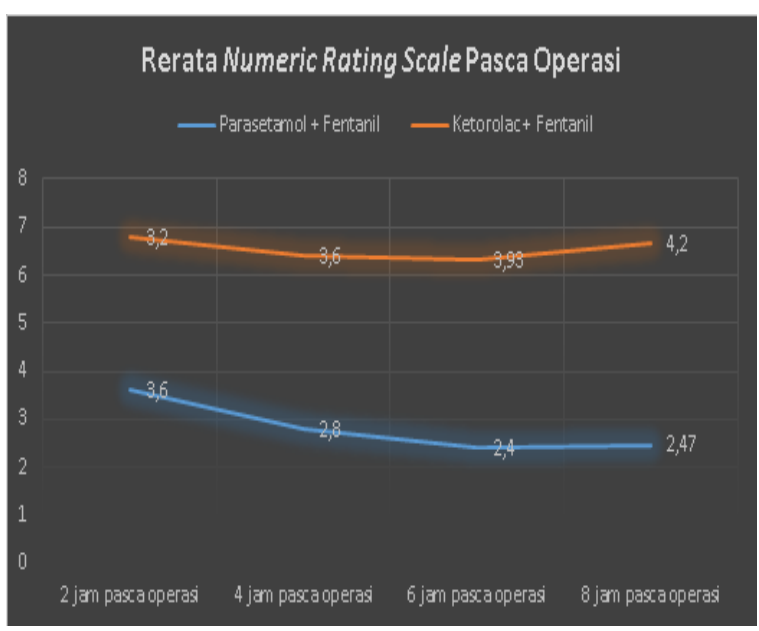

Gambar 2. Perbandingan Rerata NRS antara Paracetamol+Fentanyl dengan Ketorolac+Fentanyl

bahwa terdapat perbedaan efektivitas pemberian paracetamol-fentanyl dengan ketorolac-fentanyl sebagai analgetik pasca operasi seksio sesarea, dimana paracetamol lebih efektif dibandingkan dengan ketorolac.

\section{Pembahasan}

Tindakan operasi seksio sesarea merupakan proses persalinan dimana janin dilahirkan melalui insisi pada dinding perut dan dinding rahim yang utuh dengan indikasi tertentu untuk melahirkan janin dengan berat diatas 500 gram. ${ }^{7}$ Hampir semua prosedur pembedahan dan tindakan medis, baik pembedahan mayor maupun minor yang disertai dengan cedera saraf, beresiko menimbulkan nyeri pascabedah. Nyeri pasca seksio sesarea merupakan nyeri akut sedang berat sehingga untuk penanganannya sesuai step ladder WHO adalah dengan opiod kuat dosis tunggal atau bisa dikombinasi dengan NSAID atau adjuvant yang lain sehingga dosis pemakaiannya dapat 
diturunkan 20\%-50\%. Pada kasus seksio sesarea, fentanyl masih menjadi agen opioid pilihan dengan pertimbangan efek sampingnya yang lebih minimal dibandingkan opioid yang lain.

Paracetamol atau acetaminofen merupakan derivat para amino fenol. Paracetamol juga merupakan metabolit aktif fenasetin. Paracetamol merupakan obat lain pengganti aspirin yang efektif sebagai obat analgesikantipiretik. ${ }^{8}$ Ketorolac merupakan OAINS non selektif. Bekerja melalui penghambatan enzim COX 1 dan 2. COX-1 bersifat selalu aktif, mensintesis prostaglandin untuk menjaga organ (protektif). Sedangkan COX-2 bersifat aktif bila terdapat inflamasi. Terdapat 3 kerja utama OAINS: antipiretik, pada keadaan demam hambatan prostaglandin mengembalikan pusat termoregulasi di hipotalamus ke titik normal; analgesi, efektif mengurangi nyeri yang disertai inflamasi, dan fentanyl adalah zat sintetik seperti petidin dengan kekuatan 100x morfin. Fentanyl merupakan opioid sintetik dari kelompok fenilpiperedin. Lebih larut dalam lemak dan lebih mudah menembus sawar jaringan. ${ }^{5}$

Hasil penelitian menunjukkan hasil bahwa pada 2 jam pasca operasi diketahui antara kelompok paracetamol dan ketorolac tidak terdapat perbedaan yang signifikan dengan nilai $\mathrm{p}=0,495(\mathrm{p}>0,05)$, dimana NRS pada kelompok paracetamol-fentanyl rata-rata 3,60+1,45 dan ketorolac-fentanyl rata-rata 3,20+1,57. Pada 4 jam pasca operasi diketahui antara kelompok paracetamol dan ketorolac tidak terdapat perbedaan yang signifikan dengan nilai $p=0,091(p>0,05)$, dimana NRS pada kelompok paracetamol-fentanyl rata-rata $2,80+1,01$ dan ketorolac-fentanyl rata-rata 3,60+1,45. Pada 6 jam pasca operasi diketahui antara kelompok paracetamol-fentanyl dan ketorolac-fentanyl terdapat perbedaan yang signifikan dengan nilai $\mathrm{p}=0,000(\mathrm{p}<0,05)$, dimana NRS pada kelompok paracetamol rata-rata $2,40+0,99$ dan ketorolac rata-rata $3,93+0,88$. Pada 8 jam pasca operasi diketahui antara kelompok paracetamol-fentanyl dan ketorolac-fentanyl terdapat perbedaan yang signifikan dengan nilai $\mathrm{p}=0,000(\mathrm{p}<0,05)$ dimana NRS pada kelompok paracetamol-fentanyl rata- rata $2,47+0,74$ dan ketorolac-fentanyl rata-rata $4,20+0,86$. Pada kelompok paracetamol-fentanyl terdapat perbedaan yang signifikan pada jam ke- 2 , ke- 4 , ke- 6 , dan ke- 8 pasca operasi dengan nilai $\mathrm{p}=0,005(\mathrm{p}<0,05)$, pada ketorolac-fentanyl terdapat perbedaan yang signifikan pada jam ke2 , ke- 4 , ke- 6 , dan ke- 8 pasca operasi dengan nilai $\mathrm{p}=0,023(\mathrm{p}<0,05)$ dimana kelompok ParasetamolFentanyl dengan skor NRS cenderung turun, dan kelompok ketorolac-fentanyl dengan skor NRS cenderung meningkat. Paracetamol memiliki penghambatan prostaglandin sentral yang setara dengan aspirin. Paracetamol bekerja melalui 3 mekanisme: menghambat sintesis prostaglandin di sel, menghambat enzim siklooksigenase di pusat, dan bekerja di kemoreseptor nyeri di perifer. ${ }^{3}$ Paracetamol memiliki efek analgesik dan antipiretik setara dengan aspirin, sehingga obat ini merupakan pengganti yang cocok untuk aspirin, walaupun perlu diingat bahwa paracetamol tidak memiliki efek anti radang. Obat ini sangat bermanfaat bagi pasien yang kedapatan dikontraindikasikan menggunakan aspirin, misalkan pada pasien ulser lambung atau jika perpanjangan waktu perdarahan akibat aspirin akan merugikan.

Paracetamol sendiri tidak adekuat untuk terapi peradangan seperti artritis rematoid, walaupun dapat difungsikan sebagai analgesik tambahan untuk terapi antiradang. Untuk analgesia ringan, paracetamol merupakan obat yang lebih disukai pada penderita yang alergi dengan aspirin. ${ }^{9}$ Sedangkan ketorolac merupakan OAINS non selektif. Bekerja melalui penghambatan enzim COX 1 dan 2. COX-1 bersifat selalu aktif, mensintesis prostaglandin untuk menjaga organ (protektif). Sedangkan COX-2 bersifat aktif bila terdapat inflamasi. Terdapat 3 kerja utama OAINS: antipiretik, pada keadaan demam hambatan prostaglandin mengembalikan pusat termoregulasi di hipotalamus ke titik normal; analgesi, efektif mengurangi nyeri yang disertai inflamasi; dan antiinflamasi, menurunkan tandatanda klasik inflamasi seperti tumor, rubor, kalor, dolor, dan functiolaesa. ${ }^{4}$ Ketorolac adalah bentuk rantai campuran rasemik dari $\mathrm{S}$ dan $\mathrm{R}$ enantiomer. Bersihan $\mathrm{S}$ enantiomer dua kali lebih cepat dari $\mathrm{R}$ enantiomer. Bersihan tidak tergantung dari 
rute pemberian obat. Hal ini berarti konsentrasi rasio $S / R$ dalam plasma semakin menurun setelah pemberian obat. Penelitian lain menyebutkan waktu paruh ketorolac berkisar antara 5-6 jam. ${ }^{9}$ Sebagai suatu analgesik, fentanyl 100 kali lebih poten dibandingkan dengan morfin. Awitan yang cepat dan lama aksi yang singkat mencerminkan kelarutan lipid yang lebih besar dari fentanyl dibandingkan dengan morfin. Fentanyl meningkatkan aksi anestetik lokal pada blok saraf tepi. Keadaan itu sebagian disebabkan oleh sifat anestesi lokal yang lemah (dosis yang tinggi menekan hantara saraf) dan efeknya terhadap reseptor opioid pada terminal saraf tepi. Fentanyl dikombinasikan dengan droperidol untuk menimbulkan neureptanalgesia. ${ }^{10}$

Hasil penelitian menunjukkan bahwa pemberian paracetamol lebih efektif dalam menurunkan rasa nyeri dibandingkan dengan ketorolac sebagai analgetik pasca operasi seksio sesarea. Penelitian ini memiliki hasil yang sesuai dengan penelitian lain, yang menyatakan bahwa parasetamol memiliki efektifitas yang baik dibandingkan dengan ketorolac dalam penanganan nyeri pasca seksio sesarea, dengan hasil uji ManWhitney $\mathrm{p}=0,088$. Oleh karena itu, hipotesis yang menyatakan "ada perbedaan efektivitas pemberian paracetamol dengan ketorolac sebagai analgetik pasca operasi seksio sesarea telah terbukti. Kombinasi paracetamol-fentanyl lebih efektif dibandingkan dengan kombinasi ketorolac-fentanyl. Hal ini menunjukkan potensi penggunaan kombinasi paracetamol+fentanyl dalam aplikasi praktik klinis kasus nyeri pasca seksio sesarea.

Penelitian ini masih memiliki keterbatasan yaitu jumlah sampel yang kecil dan metode pengukuran nyeri hanya menggunakan skor NRS. Jumlah sampel yang kecil tentunya akan berdampak pada tingkat signifikansi dan tingkat korelasi antar variabel. Selain itu, metode pengukuran pada penelitian ini baru terbatas pada penggunaan skor NRS, sehingga tidak dapat menggambarkan efektifitas obat secara obyektif. Berdasarkan hasil penelitian yang telah dilakukan pada 30 pasien yang menjalani operasi seksio sesarea dengan anestesi spinal dengan ASA I dan II menggunakan lidocain 5\% di instalasi bedah sentral RSUD Dr. Moewardi Surakarta, dapat disimpulkan bahwa terdapat perbedaan efektivitas pemberian kombinasi paracetamolfentanyl dengan kombinasi ketorolac-fentanyl sebagai analgetik pasca operasi seksio sesarea, dimana kombinasi paracetamol-fentanyl lebih efektif dibandingkan dengan ketorolac-fentanyl. Saran dapat dilakukan penelitian dalam skala yang lebih besar diperlukan agar hasil penelitian dapat lebih merepresentasikan karakteristik populasi. Penambahan alat ukur nyeri selain skor NRS seperti kuesioner nyeri dan sitokin nyeri dapat digunakan pada penelitian selanjutnya agar dapat memperoleh perbandingan hasil yang optimal.

\section{Simpulan}

Berdasarkan hasil penelitian yang telah dilakukan pada 30 pasien yang menjalani operasi seksio sesarea dengan anestesi spinal dengan ASA I dan II menggunakan lidocain $5 \%$ di instalasi bedah sentral RSUD Dr. Moewardi Surakarta, dapat disimpulkan bahwa terdapat perbedaan efektivitas pemberian kombinasi parasetamolfentanyl dengan kombinasi ketorolac-fentanyl sebagai analgetik post operasi seksio sesarea, dimana kombinasi paracetamol-fentanyl lebih efektif dibandingkan dengan ketorolac-fentanyl. Penelitian ini masih memiliki keterbatasan terkait jumlah sampel. Oleh karena itu, penelitian dalam skala yang lebih besar diperlukan agar hasil penelitian dapat lebih bermakna.

\section{Daftar Pustaka}

1. Suryati T. Percentage of Sectio Caesaria in Indonesia is Passad the Maximum Standard, is it in accordance to Medical Indication. Bul Penelit Sitem Kesehatan Pus Teknol Interv Kesehatan Masyarakat, Kebijak Kesehatan dan Pemberdaya Masyarakat, Badan Penelit dan Pengemb Kesehatan, Kementeri Kesehat RI. 2012.

2. Hutchison RW. Challenges in acute post operative pain management. Am J Heal Syst 
Pharm. 2007;15(64):2-5.

3. Egan H. Pharmacology and Physiology For Anesthesia. 2nd ed. Toronto: Saunders, 2018, 774-79.

4. Jordan S, White J. Non-steroidal anti-inflammatory drugs. Clin Issues Nurs Stand. 20001;15(23): 45-52.

5. Butterworth IV JF, Mackey DC, Wasnick JD. Morgan \& Mikhail's Clinical Anesthesiology, 5th ed. Morgan \& Mikhail's Clinical Anesthesiology. New York: Mc Graw Hill; 2013, 309-41.

6. WHO. WHO Pain Relief Ladder for cancer pain relief. [Internet]. 2015 [cited 2015 Sep 14]. Available from: www.who.int/cancer/ palliative/painladder/en/
7. Wiknjosastro H. Ilmu Bedah Kebidanan. Jakarta: PT Bina Pustaka Sarwono Prawirohardjo; 2010, 56-9.

8. Haydar B. Stoelting'S Pharmacology and physiologyinanesthetic practice[Internet].5th edition. University of Michigan; 2015, 1445. Available from: https://anesthesiology.pubs. asahq.org/article.aspx? articleid=2294677.

9. Wilmana P, Gunawan S. Analgetik Antipiretik, Analgesik Antiinflamasi Non Steroid dan Obat Gangguan Sendi Lainnya. Dalam: Farmakologi dan Terapi. Jakarta: Balai Penerbit FKUI; 2009, 204.

10. Katzung B. Farmakologi Dasar dan Klinik. Alih bahasa, staf dosen farmakologi fakultas kedokteran UNSRI. 8th ed. Agoes A, editor. Jakarta: EGC; 2011. 559-77. 